\title{
miR-590-5p inhibits tumor growth in malignant melanoma by suppressing YAP1 expression
}

\author{
KUANHOU MOU ${ }^{1}$, MEILING DING ${ }^{2}$, DAN HAN ${ }^{1}$, YAN ZHOU ${ }^{1}$ \\ XIN MU ${ }^{1}$, WENLI LIU ${ }^{1}$ and LIJUAN WANG ${ }^{1}$ \\ ${ }^{1}$ Department of Dermatology, The First Affiliated Hospital of Xi'an Jiaotong University, Xi'an, Shaanxi 710061; \\ ${ }^{2}$ State Key Laboratory of Cancer Biology, National Clinical Research Center for Digestive Disease, \\ Xijing Hospital of Digestive Diseases, The Fourth Military Medical University, Xi'an, Shaanxi 710069, P.R. China
}

Received January 15, 2018; Accepted July 25, 2018

DOI: $10.3892 /$ or.2018.6633

\begin{abstract}
The microRNAs (miRNAs/miRs) involved in the carcinogenesis and progression of malignant melanoma (MM) remain unclear. In the present study, miR-590-5p was identified to be upregulated in MM cells compared with human melanocytes using a reverse transcription-quantitative polymerase chain reaction to screen established oncogenic and tumor suppressor miRNAs. miR-590-5p was demonstrated to inhibit the cell proliferation and tumor growth of MM cells in vitro and in vivo by performing Cell Counting Kit-8 and tumour xenograft assays, respectively. In addition, flowcytometry assays indicated that miR-590-5p induced cell apoptosis and cell cycle arrest at the G1 stage in MM cells. Finally, luciferase assays and western blot analysis results confirmed that the transcriptional regulator Yes-associated protein 1 (YAP1) is upregulated and inversely associated with miR-590-5p expression in MM cells, and is the direct target and functional mediator of miR-590-5p in MM. Altogether these results reveal the functional and mechanistic link between miR-590-5p and YAP1 in the progression of MM. Therefore, miR-590-5p is a potential therapeutic target in MM.
\end{abstract}

\section{Introduction}

Malignant melanoma (MM) is one of the most aggressive forms of cutaneous neoplasms, and its incidence is notably increasing (1). It is estimated that there will be 87,110 newly

Correspondence to: Professor Lijuan Wang, Department of Dermatology, The First Affiliated Hospital of Xi'an Jiaotong University, 277 Yanta West Road, Xi'an, Shaanxi 710061, P.R. China E-mail: 6945216juan@163.com

Abbreviations: MM, malignant melanoma; miRNA/miR, microRNA; 3'-UTRs, 3'-untranslated regions; HM, human melanocytes; YAP1, Yes-associated protein 1

Key words: malignant melanoma, microRNA-590-5p, Yes-associated protein 1, proliferation, apoptosis diagnosed MM cases and 9,730 MM-associated mortalities in 2017 in the United States (2). Despite substantial improvement in the diagnosis and treatment of MM in previous years, the prognosis remains poor for patients with $\mathrm{MM}$ diagnosed at metastatic stages, with a median survival time of 6-9 months and a 5-year survival rate of $<15 \%$ (3-6). Thus, identifying effective biomarkers for the early detection and efficient evaluation of prognosis of MM following surgery is crucial.

MicroRNAs (miRNAs/miRs) comprise a group of small non-coding RNAs ( 22 nucleotides in length) (7). These miRNAs regulate the expression of a wide variety of target genes through repressing translation or inducing mRNA degradation by binding to complementary sites in 3'-untranslated regions (3'-UTRs) (8). Aberrantly expressing miRNAs may function as tumor suppressors or oncogenes, depending on the functions of their target genes (9-11). Increasingly, miRNAs have been observed in various types of cancer, and have been revealed to be involved in modulating cancer cell behavior, including cell proliferation (12), cell apoptosis (13), cell cycle (14), cell migration (15) and cell invasion (16). Previously, a number of aberrantly-expressed serum and tissue miRNAs have been employed as diagnostic or prognostic indicators in MM $(11,17,18)$.

The expression and function of miR-590-5p varies in different types of tumor. miR-590-5p was previously demonstrated to function as an oncogene, and promote the proliferation, migration and G1-S phase transition by directly inhibiting the transforming growth factor beta receptor II (TGF- $\beta$ RII) in vulvar squamous cell carcinoma (19). Conversely, miR-590-5p serves a tumor suppressor role in breast cancer, and inhibits cancer cell stemness and metastasis by targeting SRY-box 2 (20). Previously, it was revealed that miR-590-5p was downregulated in human melanoma A375 cells, and inhibited their migration and invasion ability (21). However, the precise functions and underlying mechanisms of miR-590-5p on the proliferation and apoptosis of MM cells remain unclear.

In the present study, a reverse transcription-quantitative polymerase chain reaction (RT-qPCR) was performed to detect established oncogenic and tumor suppressor miRNAs in MM cells and normal human melanocytes (HMs). Furthermore, Cell Counting Kit-8 (CCK-8), flow cytometry and tumor xenograft 
assays were performed to detect the effects of miR-590-5p on the proliferation and apoptosis of MM cells in vitro, and tumor growth in vivo. Finally, luciferase assays and western blot analysis were performed to investigate whether Yes-associated protein 1 (YAP1) was the functional mediator of miR-590-5p in MM cells.

\section{Materials and methods}

Cell culture. Human MM cell lines A2058, A375, normal epidermal melanocytes HEMa-LP and 293 cells were obtained from the Cell Bank of the Chinese Academy of Sciences (Shanghai, China), where they were characterized by mycoplasma detection, DNA-fingerprinting, isozyme detection and cell vitality detection, performed by the Cell Bank of the Chinese Academy of Sciences. A2058 and A375 cells were cultured in Dulbecco's modified Eagle's medium (DMEM; Invitrogen; Thermo Fisher Scientific, Inc., Waltham, MA, USA) supplemented with $10 \%$ fetal bovine serum (HyClone; GE Healthcare Life Sciences, Logan, UT, USA) at $37^{\circ} \mathrm{C}$ in a humidified atmosphere of $95 \%$ air and $5 \% \mathrm{CO}_{2}$. HMs isolated from human foreskin specimens from patients who received circumcision at the First Affiliated Hospital of Xi'an Jiaotong University and provided written informed consent for the use of their excised foreskin. Ethical approval was obtained from the Ethics Committee of Xi'an Jiaotong University (Xi'an, China). HM and HEMa-LP cells were cultured in Medium 254 (Invitrogen; Thermo Fisher Scientific, Inc.) supplemented with $\mathrm{HM}$ growth supplement at $37^{\circ} \mathrm{C}$ in a humidified atmosphere of 95\% air and $5 \% \mathrm{CO}_{2}$.

Oligonucleotide transfection. miR-590-5p negative control (NC; sequence, GUCCAGUGAAUUCCCAG), miR-590-5p inhibitors (sequence, GACGUAAAAUACUUAUUCGAG), miR-590-5p mimics (sequence, GAGCUUAUUCAUAAA AUGCAG), YAP1 NC (antisense, CCGGTAAATTTCTGA AATTTATTTCAAGAGATTTCTAAATCTCATCCTGAG TCTCTCTTTTTG and sense, AATTCAAAAAGACAGGAC TTTAGAAATTCTCTTGAAATCCATCAGGAAGAGGAC CTGTTTG) and YAP1 small interfering RNA (siRNA; antisense, CCGGCAGGCCTCCTCTTCCTGATGGATTTCAGA GAATCCATCAGGAAGAGGACCTGTTTG and sense, AAT TCAAAACAGGTCCTCTTCCTGATGGATTCTCTTGAA ATCCATCAGGAAGAGGACCTGTTTTG) were purchased from Shanghai GenePharma Co., Ltd. (Shanghai, China). When the confluence of A375 and A2058 cells reached 50-60\% in a 6 -well plate, oligonucleotides $(50 \mathrm{nmol})$ were mixed with $5 \mu 1$ Lipofectamine ${ }^{\circledR} 2000$ (Thermo Fisher Scientific, Inc.) in $500 \mu \mathrm{l}$ serum-free DMEM (Life Technologies; Thermo Fisher Scientific, Inc.). The transfection solutions were added to each well containing $500 \mu 1$ serum-free DMEM (Life Technologies; Thermo Fisher Scientific, Inc.). Once the cells were incubated with oligonucleotides for $24 \mathrm{~h}$, the culture medium was changed to to DMEM (Invitrogen; Thermo Fisher Scientific, Inc.) supplemented with $10 \%$ fetal bovine serum (HyClone; GE Healthcare Life Sciences). Following transfection, cell samples were collected at $48 \mathrm{~h}$ for further analyses.

$R T$-qPCR. For miR590-5p quantification, total miRNA was extracted from A375 and A2058 cells using the miRNeasy
RNA isolation kit (Qiagen GmbH, Hilden, Germany) according to the manufacturer's protocol. Total miRNA samples were reverse-transcribed into cDNA using the miScript Reverse Transcription kit (Qiagen GmbH, Hilden, Germany) according to the manufacturer's protocol with a miR-590-5p specific primer and universal small nuclear U6 RNA was used as an internal loading control. RT was performed at $45^{\circ} \mathrm{C}$ for $60 \mathrm{~min}$ and $70^{\circ} \mathrm{C}$ for $10 \mathrm{~min}$. TaqMan miRNA RT-qPCR (Applied Biosystems; Thermo Fisher Scientific, Inc.) were used to detect and quantify miR-590-5p and U6 expression. For YAP1 quantification, total RNA was extracted from the cells using TRIzol reagent (Sigma-Aldrich; Merck KGaA, Darmstadt, Germany) according to the manufacturer's protocol. RNA samples were then reverse-transcribed into cDNA using PrimeScript ${ }^{\mathrm{TM}}$ RT Master Mix (Takara Bio, Inc., Otsu, Japan) according to the manufacturer's protocol with a YAP1 specific primer and U6 RNA was used as an internal loading control. SYBR Mix (Takara Bio, Inc.) was used to detect and quantify YAP1 and $\beta$-actin expression. RT-qPCR assays were performed under the following thermocycling conditions: $95^{\circ} \mathrm{C}$ for $5 \mathrm{~min}$, followed by 45 cycles of $95^{\circ} \mathrm{C}$ for $15 \mathrm{sec}, 60^{\circ} \mathrm{C}$ for $30 \mathrm{sec}$ and $72^{\circ} \mathrm{C}$ for $30 \mathrm{sec}$. Data were analyzed with 7500 software v.2.0.1 (Applied Biosystems; Thermo Fisher Scientific, Inc.), with the automatic Cq setting for adapting the baseline and threshold for $\mathrm{Cq}$ determination (22). Each sample was examined in triplicate. The primer sequences used in the present study are listed in Table I.

$C C K-8$. A2058 cells transfected with miR-590-5p NC and miR-590-5p mimics (used $24 \mathrm{~h}$ after transfection) and A375 cells transfected with miR-590-5p NC and miR-590-5p inhibitors (used $24 \mathrm{~h}$ after transfection) were seeded in a 96-well culture plate at a density of 2,000 cells per well. Each group was established in nine wells. CCK-8 reagents (MedChemExpress, Monmouth Junction, NJ, USA) were added into each well 24, 48, 72, 96 and $120 \mathrm{~h}$ after seeding, and each group was cultured for $50 \mathrm{~min}$ at $37^{\circ} \mathrm{C}$ in a humidified atmosphere of $95 \%$ air and $5 \% \mathrm{CO}_{2}$. The OD values were measured at $490 \mathrm{~nm}$ in a Microplate Reader.

Flow cytometry. A375 and A2058 cells in 6 well culture plate were harvested by trypsinization at $37^{\circ} \mathrm{C}$ for $5 \mathrm{~min}$, and wash three times with PBS. For cell apoptosis, cells were suspended in $500 \mu \mathrm{l}$ binding buffer at a density of $2 \times 10^{6}$ cells $/ \mathrm{ml}$, and incubated with Annexin V-fluorescien isothiocyanate and propidium iodide (PI; BD Biosciences, San Jose, CA, USA) for $15 \mathrm{~min}$ in the dark at room temperature. For cell cycle analysis, $2 \times 10^{6}$ cells $/ \mathrm{ml} \mathrm{A} 2058$ and A375 cells were fixed using $75 \%$ ethanol at $4^{\circ} \mathrm{C}$ for $12 \mathrm{~h}$. PI was added into A2058 and A375 cells transfected with miR-590-5p NC, inhibitors or mimics and incubated for $20 \mathrm{~min}$ in the dark at room temperature. Cell apoptosis and cell cycle was then analyzed using a flow cytometer and Kaluza Analysis Software version 2.0 (Beckman Coulter, Inc., Brea, CA, USA).

Western blot analysis. A375 and A2058 cells were washed in PBS three times prior to proteins being extracted. Then the cells were lysed using RIPA buffer for $30 \mathrm{~min}$ on ice (Xi'an Jing Cai Biological Technology Co., Ltd., Xi'an, China), each protein sample $(30 \mu \mathrm{g})$ was denatured in SDS sample buffer 
Table I. Primers used for reverse transcription-quantitative polymerase chain reaction.

Gene name

Forward primer 5'-3'

Reverse primer 5'-3'

$\begin{array}{ll}\text { Yes-associated protein } 1 & \text { ACCCACAGCTCAGCATCTTCG } \\ \beta \text {-actin } & \text { CGTCTTCCCCTCCATCGT } \\ \text { microRNA-590-5p } & \text { GGAATTCTTCAGTTGTAACCCAG } \\ \text { U6 } & \text { CTCGCTTCGGCAGCACA }\end{array}$

TGGCTTGTTCCCATCCATCAG

GAAGGTGTGGTGCCAGATTT CGGGATCCTTGAGATGTCACCAA AACGCTTCACGAATTTGCGT

and separated via $10 \%$ SDS/PAGE gel. Separated proteins were transferred onto polyvinylidene fluoride membranes (EMD Millipore, Billerica, MA, USA) blocked with 5\% bovine serum albumin (Beyotime Institute of Biotechnology, Haimen, China) for $2 \mathrm{~h}$ at room temperature, and incubated overnight with primary antibodies at $4^{\circ} \mathrm{C}$. Blotting was performed with primary antibodies against YAP1 (1:300; cat no. 14074; Cell Signaling Technology,Inc., Danvers, MA,USA). Goat anti-rabbit immunoglobulin horseradish peroxidase-conjugated $\mathrm{F}(\mathrm{ab}) 2$ fragments (1:5,000; cat no. TA130071; OriGene Technologies, Inc., Rockville, MD, USA) were used as secondary antibodies and incubated for $2 \mathrm{~h}$ at room temperature. $\beta$-actin $(1: 4,000$; cat no. ab8226; Abcam, Cambridge, UK) was used as a loading control and incubated overnight at $4{ }^{\circ} \mathrm{C}$. Blots were then washed three times (10 $\mathrm{min} / \mathrm{wash}$ ) in tris buffered saline with $0.1 \%$ Tween-20 and developed using an enhanced chemiluminescence system (Xi'an Jing Cai Biological Technology Co., Ltd.). ImageJ 1.8.0 (National Institutes of Health, Bethesda, MD, USA) was used to analyze the gray values of each blot.

Tumour xenograft assays. For tumorigenesis assays, A2058 cells were engineered to stably overexpress miR-590-5p and luciferase, using a lentiviral-based system (cat no. 73153; pLenti6.3; Shanghai GeneChem, Inc., Shanghai, China) In brief, pri-miR-590-5p sequence was cloned into pLenti6.3 vector (Shanghai GeneChem, Inc.). Then, pLenti-miR-590-5p-Luci (50 nmol) was co-transfected into 293 cells with psPAX2 and PMD2G by using Lipofectamine $2000^{\circledR}$ (Thermo Fisher Scientific, Inc.) according to the manufacturer's protocol. Once the 293 cells were incubated with oligonucleotides for $8 \mathrm{~h}$ at $37^{\circ} \mathrm{C}$, the culture medium was changed to DMEM (Invitrogen; Thermo Fisher Scientific, Inc.) supplemented with $10 \%$ fetal bovine serum (HyClone; GE Healthcare Life Sciences). Following transfection, viral particles were collected at $48 \mathrm{~h}$, and centrifuged together at $1,000 \mathrm{x}$ g for $5 \mathrm{~min}$ at $4^{\circ} \mathrm{C}$, then filtered through $0.45 \mathrm{~nm}$ filter. Xenograft tumors were generated by the subcutaneous injection of A2058 cells $\left(5 \times 10^{6}\right)$, including A2058 pLenti-Luciferase and A2058 pLenti-miR-590-5p-Luciferase, into the hind limbs of 4-6 weeks old Balb/C female athymic nude mice (nu/nu; Animal Center of Xi'an Jiaotong University, Xi'an, China; $\mathrm{n}=5$ for each group). All mice were housed and maintained under specific pathogen-free conditions at $18-22^{\circ} \mathrm{C}$, with $20 \%$ humidity, a 12-h light and 12-h dark cycle and ad libitum access to food. The tumor size was measured using an Xenogen IVIS Kinetic imaging system and vernier caliper. Tumor volume was determined by the formula: $0.5 \times \mathrm{AxB}^{2}$, where $\mathrm{A}$ represents the diameter of the base of the tumor and $B$ represents the corresponding perpendicular value. When the mean diameter reach $1.2 \mathrm{~cm}$ or progressive tumor growth was evident, the mice were euthanasized by placing mice in sealed chambers where $5 \%$ isoflurane was introduced. Then, the tumors were collected and weighed. All experiments were ethically approved by the Animal Care and Use Committee of Xi'an Jiaotong University and performed in accordance with institutional guidelines (23).

Luciferase assays. A total of 5,000 293 cells were seeded in a 96-well plate at $70 \%$ confluence. The YAP1 wild type (WT) 3'-UTR firefly luciferase construct (pMir-YAP1 WT- 3'-UTR) was generated by inserting YAP1 WT 3'-UTR into pMir-Report vector (Ambion; Thermo Fisher Scientific, Inc.). Mutations were introduced in potential miR-590-5p binding sites using the QuikChange site-directed mutagenesis kit (Stratagene; Agilent Technologies, Inc., Santa Clara, CA, USA) according to the manufacturer's protocol. Then, a final concentration of $100 \mathrm{nM}$ miR-590-5p NC or mimics were transfected into 293 cells along with 30 ng pMir-YAP1 WT or mutant 3'-UTR luciferase reporter and $10 \mathrm{ng}$ Renilla luciferase reporter using Lipofectamine ${ }^{\circledR} 2000$, as previously stated. Cells were collected $48 \mathrm{~h}$ post-transfection, and luciferase assays were performed using a Photinus pyralis-Renilla reniformis dual luciferase reporter assay system (Promega Corporation, Madison, WI, USA) according to the manufacturer's protocol. The ratio of Photinus pyramid to Renilla of each lysate luciferase activity was determined by an Orion II Microplate Illuminometer (Titertek-Berthold, South San Francisco, CA, USA). Relative activities were expressed as the fold change in luciferase activity.

Statistical analysis. Statistical analysis was performed using IBM SPSS statistical software (version 21.0; IBM Corp., Armonk, NY, USA). A volcano plot of established oncogenic and tumor suppressor miRNA profiles in A375 cells compared with HM controls was produced, and an adjusted P-value for each miRNA was analyzed by Bonferroni's correction. Potential targets of miR-590-5p were determined by integrating the results of multiple prediction algorithms of TargetScan [TargetScan human 7.2 (24), www.targetscan. org/], PicTar [PicTar (25), https://pictar.mdc-berlin.de/] and miRNAda [miRNAda (26), http://www.microrna.org/; search term used, miR-590-5p mammal) accessed on the 12th December 2016. The differences in characteristics between 2 groups were examined using a paired Student's t-test. The differences in characteristics between 3 groups was examined using one-way analysis of variance followed by a least significant difference-t-test to detect the differences between every 2 groups. The differences of miRNA expressions in A375 and HM cells was examined by hierarchical cluster analysis. All P-values were determined from 2 -sided tests. P-value $<0.05$ was considered to indicate a statistically significant difference. 
Table II. Established miRNAs detected in the present study.

\begin{tabular}{|c|c|}
\hline miRNA name & Function \\
\hline $\operatorname{miR}-590-5 p$ & Tumor suppress \\
\hline miR-663 & Oncogene \\
\hline miR-33a & Tumor suppresso \\
\hline miR-137 & Tumor suppressor \\
\hline miR-30a & Tumor suppressor \\
\hline $\operatorname{miR}-200 \mathrm{c}$ & Tumor suppressor \\
\hline miR-378 & Tumor suppresso \\
\hline miR-7 & Tumor suppresso \\
\hline $\operatorname{miR}-215$ & Tumor suppresso \\
\hline $\operatorname{miR}-195$ & Tumor suppress \\
\hline miR-30a-5p & Tumor suppresso \\
\hline $\operatorname{miR}-874$ & Tumor suppress \\
\hline miR-1180 & Tumor suppress \\
\hline miR-136 & Tumor suppresso \\
\hline miR-497 & Tumor suppresso \\
\hline $\operatorname{miR}-31$ & Tumor suppresso \\
\hline miR-503 & Tumor suppresso \\
\hline miR-202 & Tumor suppress \\
\hline miR-105-5p & Tumor suppress \\
\hline miR-139-5p & Tumor suppress \\
\hline miR-539 & Tumor suppress \\
\hline miR-30d & Tumor suppress \\
\hline $\operatorname{miR}-493$ & Tumor suppress \\
\hline $\operatorname{miR}-491$ & Tumor suppress \\
\hline miR-337 & Tumor suppress \\
\hline miR-26a & Tumor suppress \\
\hline miR-199a-3p & Tumor suppress \\
\hline miR-557 & Tumor suppress \\
\hline $\operatorname{miR}-195$ & Tumor suppress \\
\hline $\operatorname{miR}-455-3 p$ & Tumor suppress \\
\hline $\operatorname{miR}-187$ & Tumor suppress \\
\hline $\operatorname{miR}-320$ & Tumor suppress \\
\hline miR-101 & Tumor suppress \\
\hline miR-193a-3p & Tumor suppress \\
\hline $\operatorname{miR}-4728-3 p$ & Tumor suppress \\
\hline miR-564 & Tumor suppress \\
\hline $\operatorname{miR}-18 \mathrm{a}$ & Tumor suppress \\
\hline miR-17-5p & Tumor suppress \\
\hline miR-186 & Tumor suppress \\
\hline $\operatorname{miR}-148 \mathrm{a}$ & Tumor suppresso \\
\hline $\operatorname{miR}-497$ & Tumor suppressor \\
\hline miR-1247-5p & Tumor suppresso \\
\hline $\operatorname{miR}-378$ & Tumor suppress \\
\hline miR-144-3p & Tumor suppress \\
\hline miR-211-5p & Tumor suppress \\
\hline miR-146a-5p & Tumor suppresso \\
\hline miR-143-3p & Tumor suppresso \\
\hline miR-1271 & Tumor suppressor \\
\hline $\operatorname{miR}-186$ & Tumor suppresso \\
\hline miR-193b & Tumor suppressor \\
\hline miR-126 & Tumor suppresso \\
\hline miR-30b-5p & Tumor suppress \\
\hline
\end{tabular}

Table II. Continued.

\begin{tabular}{|c|c|c|}
\hline miRNA name & Function & PMID \\
\hline miR-15a & Oncogene & 28758198 \\
\hline miR-483-5p & Oncogene & 28727371 \\
\hline miR-210-3p & Oncogene & 28693852 \\
\hline miR-193a-3p & Oncogene & 28693273 \\
\hline miR-215 & Oncogene & 28689850 \\
\hline miR-1271 & Oncogene & 28682437 \\
\hline miR-944 & Oncogene & 28680805 \\
\hline miR-138 & Oncogene & 28677784 \\
\hline miR-492 & Oncogene & 28677719 \\
\hline miR-605 & Oncogene & 28673012 \\
\hline miR-661 & Oncogene & 28656235 \\
\hline miR-30e-5p & Oncogene & 28653805 \\
\hline miR-137 & Oncogene & 28610956 \\
\hline miR-96-5p & Oncogene & 28588711 \\
\hline miR-216a & Oncogene & 28579808 \\
\hline miR-142-5p & Oncogene & 28559989 \\
\hline miR-214 & Oncogene & 28559385 \\
\hline miR-141-3p & Oncogene & 28543175 \\
\hline miR-425-5p & Oncogene & 28537672 \\
\hline $\operatorname{miR}-582$ & Oncogene & 28713947 \\
\hline miR-210-3p & Oncogene & 28693582 \\
\hline miR-20a & Oncogene & 28693582 \\
\hline miR-34a & Oncogene & 28599485 \\
\hline miR-146b-5p & Oncogene & 28560062 \\
\hline miR-126 & Oncogene & 28536606 \\
\hline miR-205 & Oncogene & 28476165 \\
\hline miR-18a-5p & Oncogene & 28471447 \\
\hline miR-141 & Oncogene & 28454307 \\
\hline miR-103 & Oncogene & 28445396 \\
\hline miR-556-3p & Oncogene & 28440444 \\
\hline $\operatorname{miR}-495$ & Oncogene & 28401017 \\
\hline miR-221 & Oncogene & 28392366 \\
\hline miR-155 & Oncogene & 28338193 \\
\hline $\operatorname{miR}-27 a$ & Oncogene & 28327189 \\
\hline miR-181 & Oncogene & 28224609 \\
\hline miR-844 & Oncogene & 28224609 \\
\hline miR-182 & Oncogene & 28122586 \\
\hline miR-125 & Oncogene & 28053194 \\
\hline miR-346 & Oncogene & 27913185 \\
\hline miR-19a & Oncogene & 27830963 \\
\hline
\end{tabular}

miR/miRNA, microRNA; PMID, PubMed-Indexed for MEDLINE.

28586038

28575858

28574724

28571042

28560455

28559978

28551819

28550686

28542597

28536606

28536082
The data were presented as the mean \pm standard deviation from three independent experiments.

\section{Results}

miR-590-5p is downregulated in MM cells. To identify the miRNAs involved in the carcinogenesis and progression of $\mathrm{MM}$, established oncogenic and tumor suppressor miRNA 
A

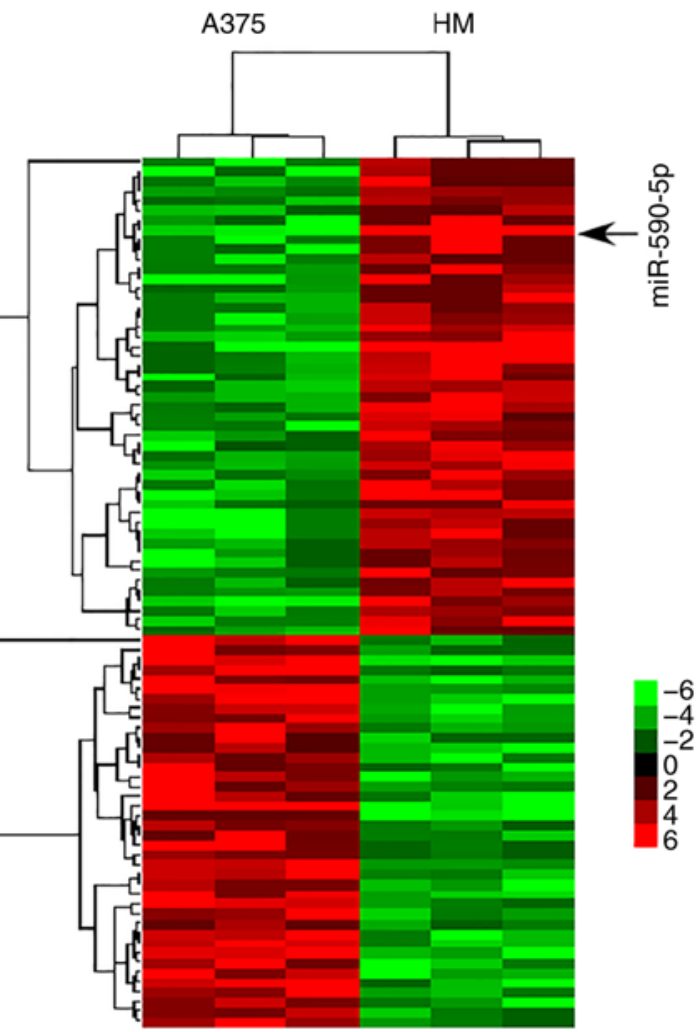

B
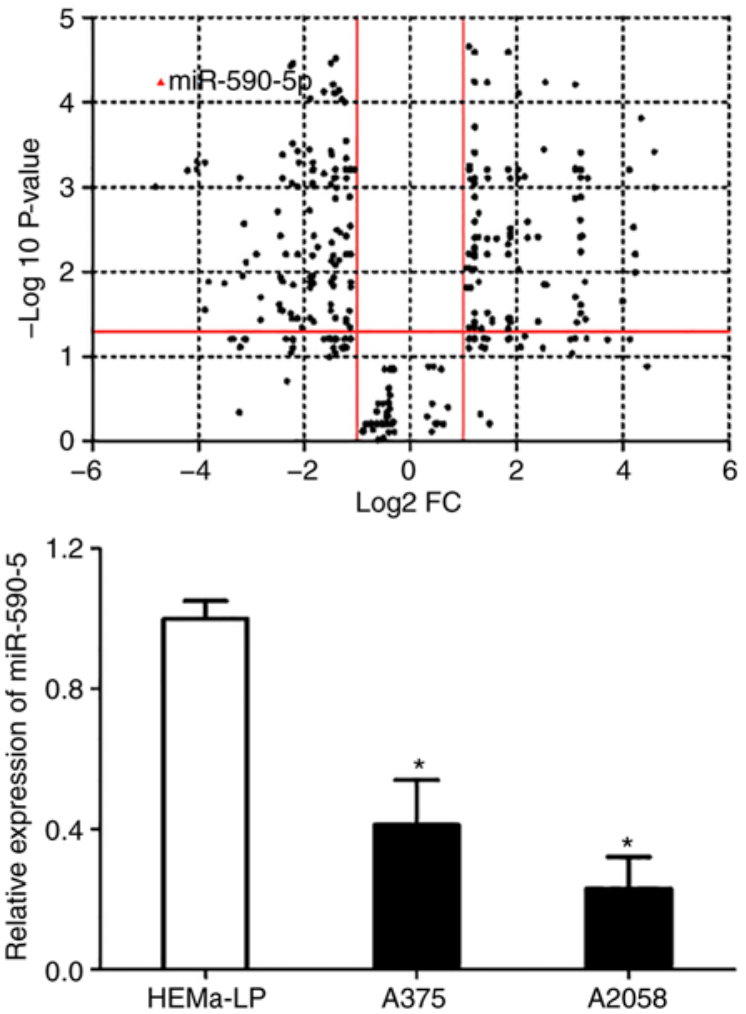

Figure 1. miR-590-5p is downregulated in A375 and A2058 cells. (A) Hierarchical cluster analysis of all established oncogenic or tumor suppressor miRNAs identified through miRNA screening in A375 cells and normal HM. (B) Volcano plot of established oncogenic and tumor suppressor miRNA profiles in A375 cells compared with HM controls. The x-axis presents the $\log _{2}$ FC in miRNA expression between A375 and HM, while the y-axis presents the Log10 of the adjusted P-value for each miRNA. Above the red line on $\mathrm{y}$-axis indicates statistical significance. $\mathrm{P}<0.05$ following Bonferroni's correction. (C) Relative expression of miR-590-5p in normal epidermal melanocytes and MM cells. Data are from three experiments and presented as the mean \pm standard deviation. ${ }^{*} \mathrm{P}<0.05$ vs. HEMa-LP cells (Student's t-test). miR/miRNA, microRNA; HM, human melanocytes; FC, fold change; MM, malignant meloma.

screening was detected in normal HMs and the MM cell line A375 by RT-qPCR (Table II). Hierarchical cluster analysis identified that miR-590-5p was commonly downregulated in A375 cells compared with the representative controls (Fig. 1A). A volcano plot revealed a significant difference in the expression of miR-590-5p in A375 cells compared with the controls ( $>4$-fold change; $\mathrm{P}<0.0001$; Fig. 1B). The significant downregulation of miR-590-5p was further confirmed using RT-qPCR in MM cell lines compared with HEMa-LP ( $\mathrm{P}<0.05$; Fig. 1C).

Effect of miR-590-5p on the proliferation and apoptosis of MM cells. To investigate the functional role of miR-590-5p in $\mathrm{MM}$ cells, gain- and loss-of function experiments were performed by transfecting miR-590-5p mimics into A2058 cells and miR-590-5p inhibitors into A375 cells. CCK-8 assays revealed that the proliferation of A2058 cells transfected with miR-590-5p mimics was significantly inhibited compared with the normal control $(\mathrm{P}<0.05$; Fig. $2 \mathrm{~A})$. Additionally, the proliferation of A375 cells transfected with miR-590p-5p inhibitors was significantly enhanced compared with the normal control (NC) cells $(\mathrm{P}<0.05$; Fig. $2 \mathrm{~B})$. Cell apoptosis assays revealed that the percentages of early apoptotic cells significantly increased in A2058 cells transfected with miR-590-5p mimics compared with NCs $(\mathrm{P}<0.05)$, and decreased in A375 cells transfected with miR-590-5p inhibitors compared with NCs ( $\mathrm{P}<0.05$; Fig. $2 \mathrm{C}$ and $\mathrm{D})$.
Effects of miR-590-5p on the cell cycle and tumorigenic ability of MM cells. Flow cytometry assays were performed to determine the effects of miR-590-5p on the distribution of cells at the various stages of the cell cycle. Compared to NCs, A2058 cells transfected with miR-590-5p mimics displayed a significant increase in the percentage of cells at the G1 stage $(\mathrm{P}<0.05)$ and a significant decrease in the percentage of cells at the $\mathrm{S}$ stage $(\mathrm{P}<0.05$; Fig. $3 \mathrm{~A}$ and $\mathrm{B})$. Meanwhile, the proportion of cells at the G1 stage significantly decreased and the proportion of cells at the $\mathrm{S}$ stage significantly increased in A375 cells transfected with miR-590-5p inhibitors compared with NCs $(\mathrm{P}<0.05$; Fig. 3C).

Next, the functional roles of miR-590-5p on the tumorigenic ability of MM cells in vivo were examined. A2058 cells were engineered to stably upregulate miR-590-5p and luciferase expression and performed tumorigenesis assays in nude mice. The cells $\left(5 \times 10^{6}\right)$ were injected into the flanks of nude mice, and tumor sizes were measured by Xenogen IVIS Kinetic imaging systems and vernier calipers every 7 days. After 35 days, the mice were sacrificed and the tumors were collected and weighed. It was revealed that miR-590-5p exhibited substantial tumor growth-inhibitory effects as assessed by the Xenogen IVIS200 System (Fig. 3D). In addition, a significant reduction of tumor sizes $(\mathrm{P}<0.05$; Fig. $3 \mathrm{E})$ and tumor weight $(\mathrm{P}<0.05 ;$ Fig. 3F $)$ was observed in the pLenti-miR-590-5p group compared with the NC group. Altogether these results indicated miR-590-5p was downregulated in MM cells and 

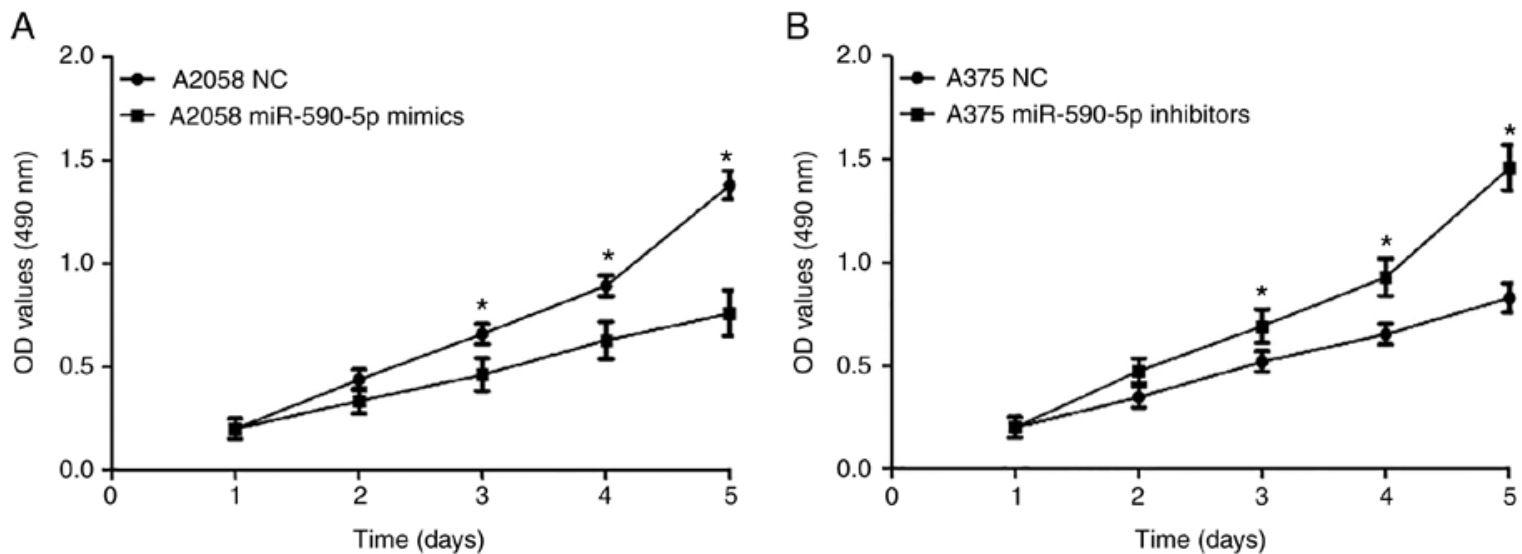

C
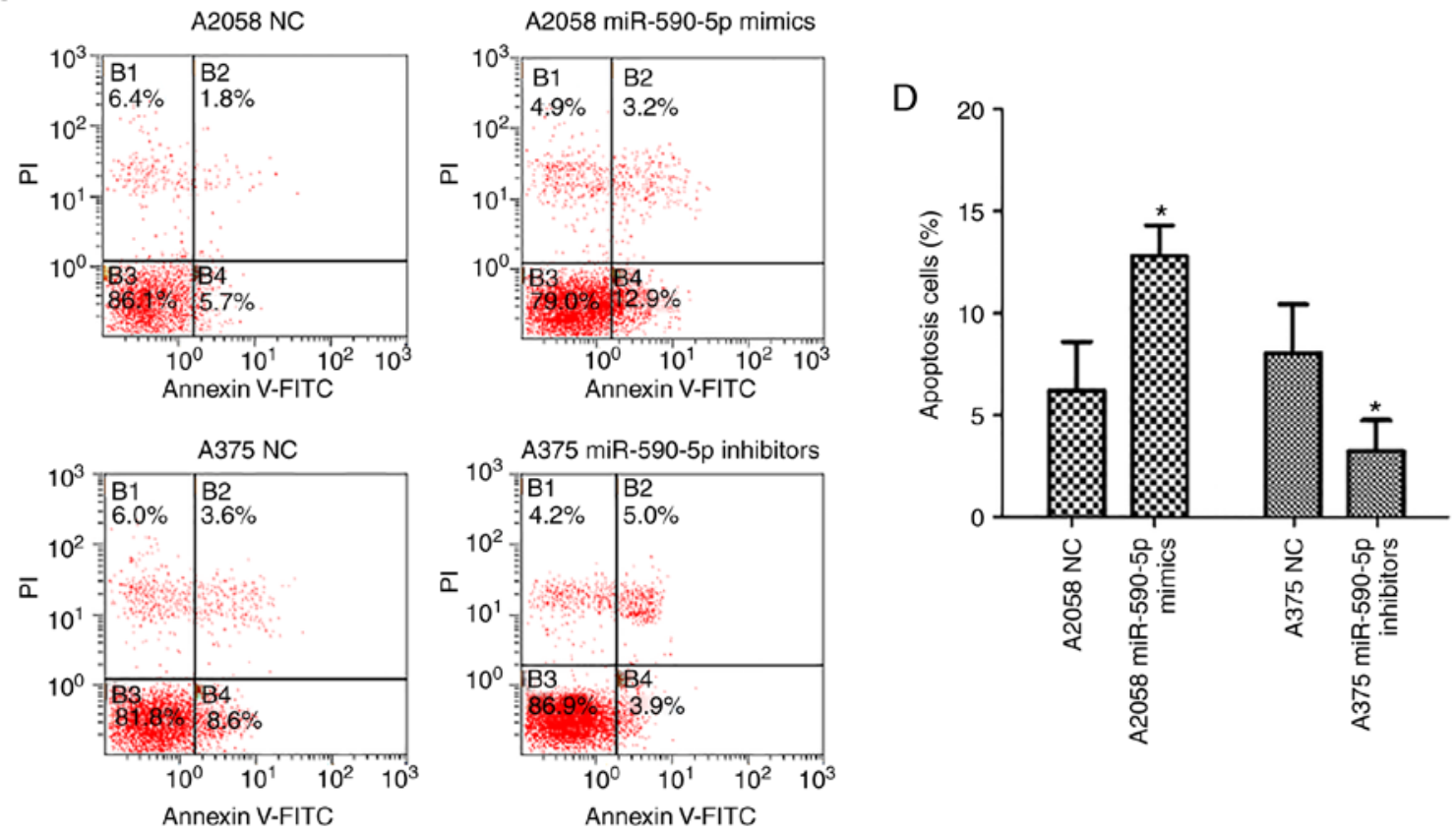

Figure 2. Effects of miR-590-5p on the cell proliferation and apoptosis of MM cells. (A) Effect of miR-590-5p mimics on the proliferation of A2058 cells were detected by CCK-8 assays. (B) Effect of miR-590-5p inhibitors on the proliferation of A375 cells were detected by CCK-8 assays. (C) Effect of miR-590-5p on the cell apoptosis of MM cells were detected by flow cytometry using Annexin V-FITC/PI kit and (D) quantified. Data are from three experiments and presented as mean \pm standard deviation. ${ }^{*} \mathrm{P}<0.05$ vs. respective NC group. (Student's t-test). miR, microRNA; CCK-8, cell counting kit-8; NC, normal control; MM, malignant myeloma; FITC, fluorescien isothiocyanate; PI, propdium iodide.

could repress cell proliferation and tumor growth in vitro and in vivo.

YAPl is the direct target of miR-590-5p. To identify the potential targets of miR-590-5p that may contribute to its tumor growth-inhibitory effects, an unbiased computational screening was performed by integrating the results of multiple prediction algorithms (TargetScan, PicTar and miRNAda). YAP1, which contains a putative miR-590-5p target site, was selected as a potential target of miR-590-5p in MM cells. YAP1 WT 3'-UTR and Mut 3'-UTR were cloned separately into a luciferase reporter vector (Fig. 4A). Luciferase reporter assays demonstrated that 293 cells co-transfected with YAP1 WT 3'-UTR and miR-590-5p mimics revealed a $>60 \%$ significant decrease in the relative luciferase activity compared with NCs $(\mathrm{P}<0.05)$. Conversely, 293 cells co-transfected with YAP1 Mut 3'-UTR and miR-590-5p resulted in imperceptible changes in relative luciferase activity compared with the NC (Fig. 4B).
Next. whether YAP1 expression was inversely associated with miR-590-5p in MM cells was examined. It was revealed that YAP1 expression was significantly upregulated in the two MM cell lines used compared with HEMa-LP cells $(\mathrm{P}<0.05$; Fig. 4C). Furthermore, RT-qPCR and western blot results revealed that the mRNA expression levels of YAP1 were significantly decreased $(\mathrm{P}<0.05)$, and the protein expression of YAP1 decreased in A2058 cells transfected with miR-590-5p mimics compared with NCs. Conversely, the expression of YAP1 at the mRNA expression level was significantly upregulated $(\mathrm{P}<0.05)$ and YAP1 protein expression was upregulated in A375 cells transfected with miR-590-5p inhibitors (Fig. 4D and E).

YAPl is a functional mediator of miR-590-5p in MM. To determine whether YAP1 is a functional mediator of miR-590-5p, YAP1 siRNA or NC and miR-590-5p inhibitors were transfected into A375 cells. As expected, silencing the expression 
A
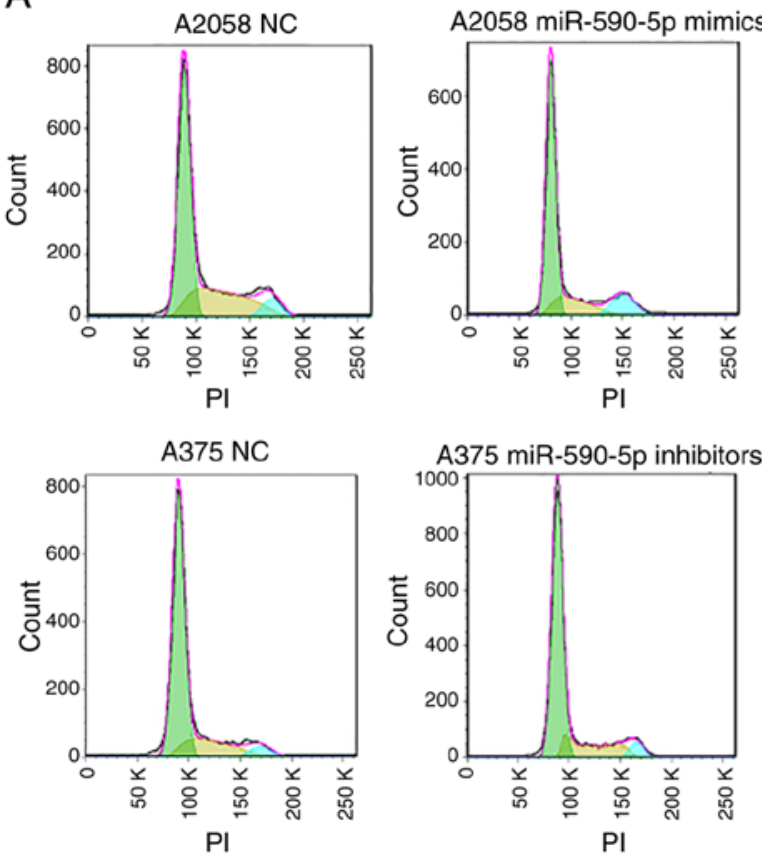

C
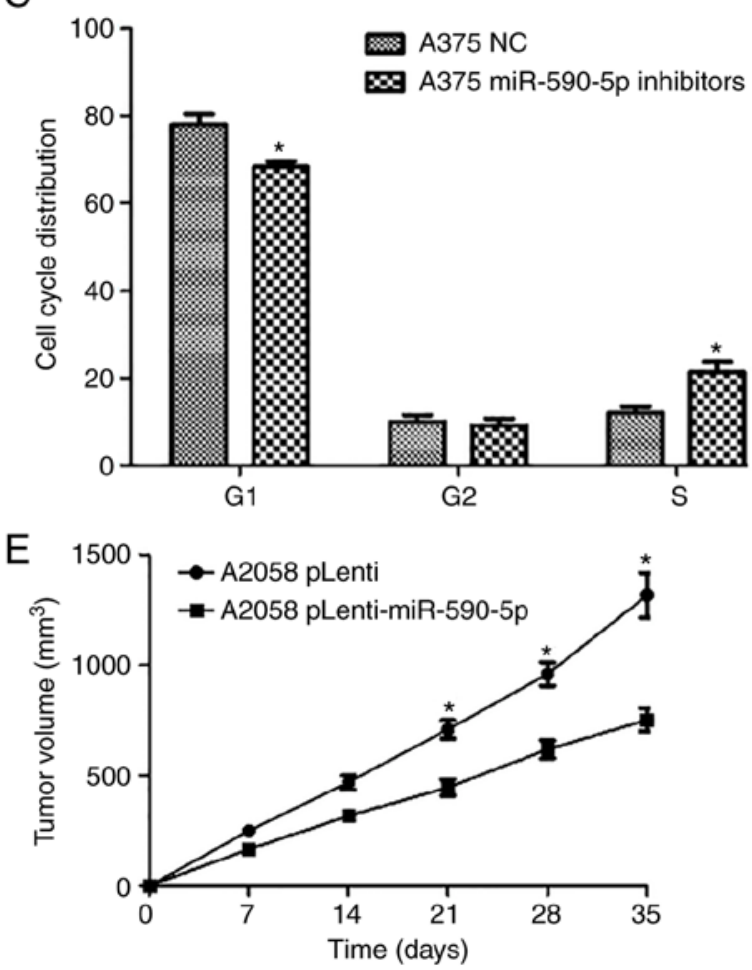
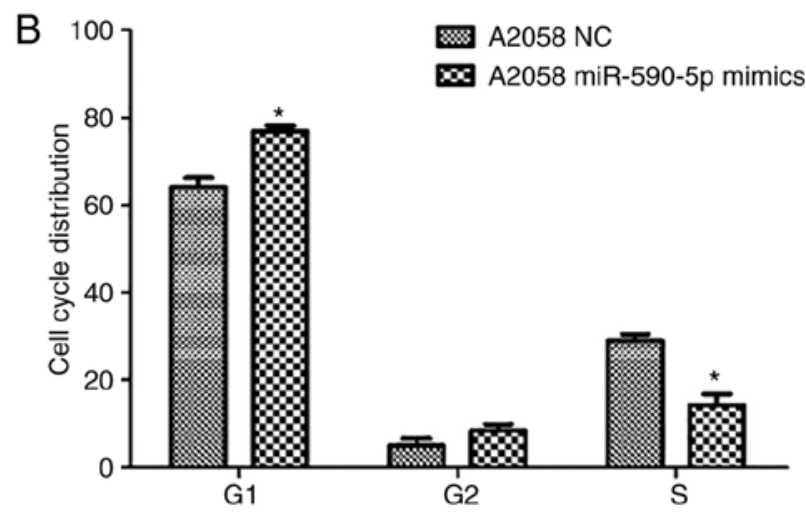

$\mathrm{D}$
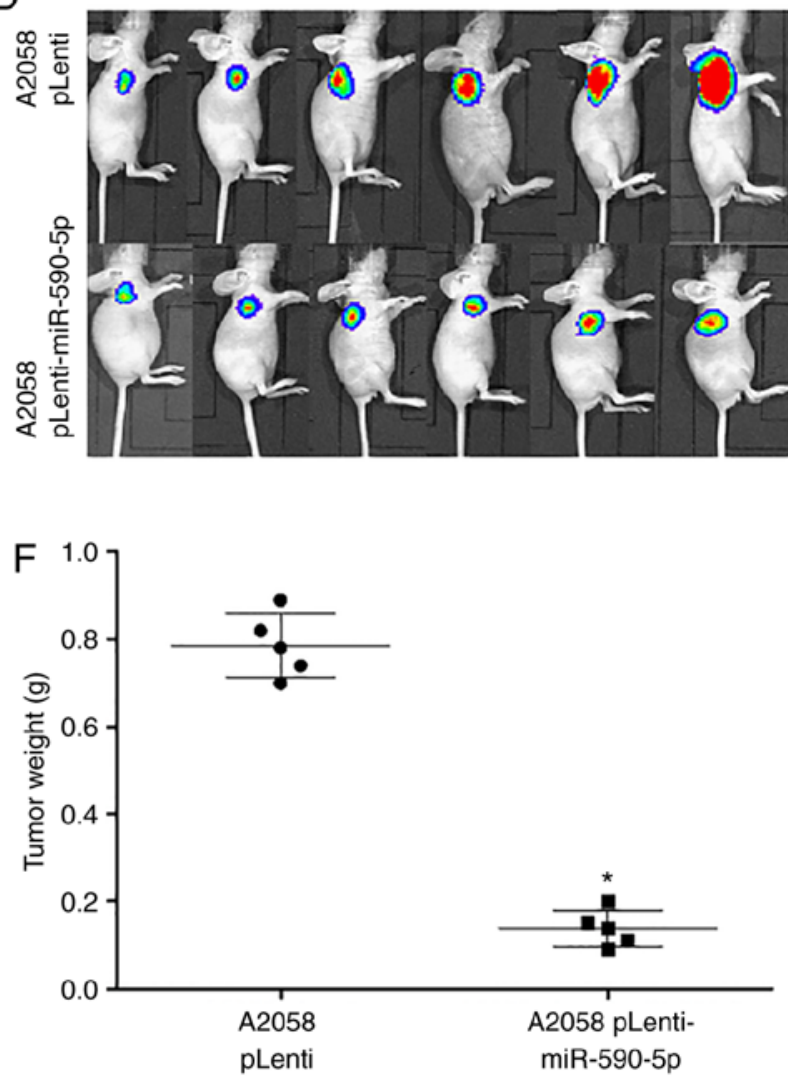

Figure 3. Effects of miR-590-5p on cell cycle and tumorigenic ability of malignant myeloma cells. (A) Effect of miR-590-5p on the cell cycle distribution of A2058 and A375 cells were detected using flow cytometry using PI. (B) Effect of miR-590-5p on the cell cycle distribution of A2058 cells. (C) Effect of miR-590-5p on the cell cycle distribution of A375 cells. (D) Tumor sizes were measured by a Xenogene IVIS Kinetic imaging system and vernier caliper every 7 days subsequent to the injection of A2058 pLenti-miR-590-5p-luciferase cells and A2058 pLenti-luciferase cells into the flanks of nude mice. (E) Tumor growth curve of A2058 pLenti-miR-590-5p-luciferase cells and A2058 pLenti-luciferase cells in nude mice. (F) Tumor weight of A2058 pLenti-miR-590-5p-luciferase groups and A2058 pLenti-luciferase groups at day 35. Data are from three experiments and presented as the mean \pm standard deviation. ${ }^{*} \mathrm{P}<0.05$ vs. respective NC group. (Student's t-test). miR, microRNA; PI, propidium iodide; NC, normal control.

of YAP1 in A375 cells transfected with miR-590-5p inhibitors attenuated the effects on cell proliferation $(\mathrm{P}<0.05$; Fig. $5 \mathrm{~A})$. In addition, the percentages of early apoptotic cells were increased in A375 cells transfected with YAP1 siRNA and miR-590-5p inhibitors compared with A375 cells transfected with YAP1 NC and miR-590-5p inhibitors ( $\mathrm{P}<0.05$; Fig. 5B and $\mathrm{C}$ ). It was also demonstrated that silencing YAP1 may rescue the effects of miR-590-5p inhibitors on the cell cycle progression of $\mathrm{A} 375$ cells $(\mathrm{P}<0.05$; Fig. 5D and $\mathrm{E})$ in addition to tumor growth $(\mathrm{P}<0.05$; Fig. $5 \mathrm{~F}$ and $\mathrm{G})$. 
A

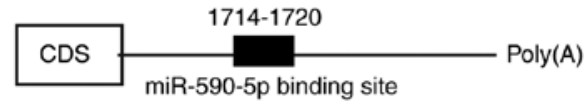

YAP1 WT 3'-UTR

miR-590-5p

YAP1 MUT 3'-UTR

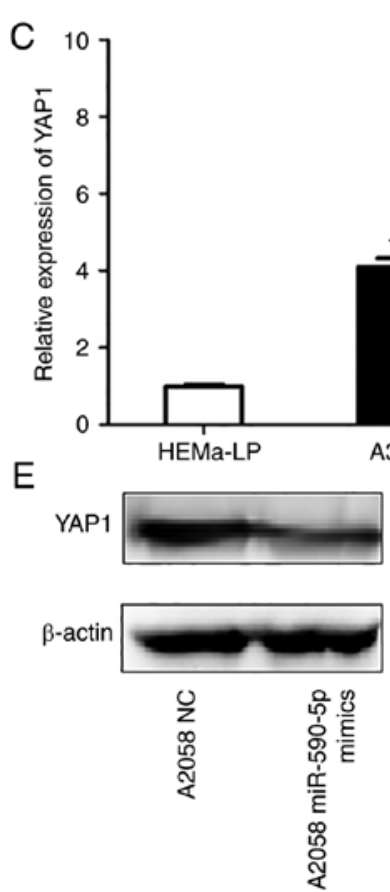

GACGUGAAAAUACUUAUUCGAG

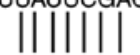

AUUAACUCUUCAAUAUAAGCUA

GACGUGAAAAUACUAUAAGCUG
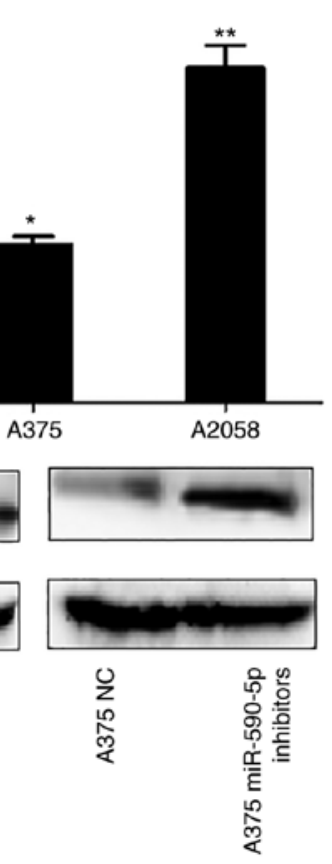
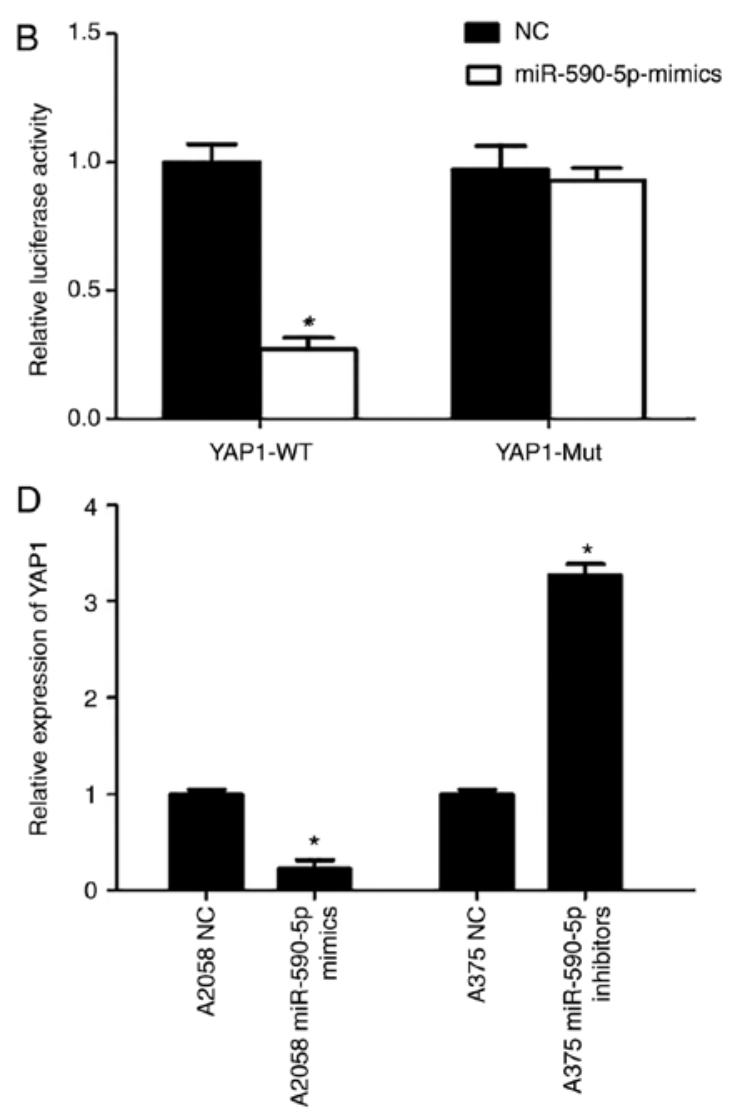

Figure 4. YAP1 is the direct target of miR-590-5p. (A) miR-590-5p and its putative binding sequence in the 3'-UTR of YAP1, a diagrammatic representation of the luciferase reporter plasmids with WT and MT YAP13'-UTR. (B) Relative luciferase activity in 293 cells following transfection with WT or Mut YAP13'-UTR plasmids co-transfected with miR-590-5p mimics. (C) Relative expression of YAP1 mRNA in normal epidermal melanocytes and MM cells. (D) Relative expression of YAP1 mRNA in MM cells transfected with miR-590-5p mimics or inhibitors. (E) Western blot analysis of YAP1 protein in MM cells transfected with miR-590-5p mimics or inhibitors. Data are from three experiments and presented as the mean \pm standard deviation. ${ }^{*} \mathrm{P}<0.05 \mathrm{vs}$. respective NC group. (Student's t-test). YAP1, Yes-associated protein 1; WT, wild type; Mut, mutant; UTR, untranslated region; NC, normal control; miR, microRNA; MM, malignant myeloma.

\section{Discussion}

In the present study, miR-590-5p was identified to be downregulated in MM cells by screening established oncogenic and tumor suppressor miRNAs and RT-qPCR. It was confirmed that miR-590-5p overexpression is able to significantly inhibit cell proliferation and induce cell cycle arrest and apoptosis in MM cells. It was also identified that miR-590-5p may inhibit MM tumor growth in vivo. Finally, it was demonstrated that YAP1 was upregulated and inversely associated with miR-590-5p expression in MM cells and that YAP1 is the direct target and functional mediator of miR-590-5p in these cells.

Dysregulated miRNAs serve notable roles in the regulation of carcinogenesis and the progression of multiple types of cancer $(10,27)$, including MM $(11,28,29)$; however, the underlying mechanism is poorly understood. Depending on their different targets, certain miRNAs may function as tumor suppressors, whilst others function as oncogenes. For example, miR-21 is upregulated in primary cutaneous melanomas associated with benign nevi $(30,31)$ and may promote cell invasion by negatively regulating tissue inhibitor of metalloprotinease-3 (32). Alternatively, miR-125b is downregulated in the sera of patients with MM and MM cells compared with healthy volunteers and human epidermal melanocytes, respectively (33-35). In the present study, it was demonstrated that miR-590-5p was downregulated in MM cells. As it was revealed that miR-590-5p inhibited proliferation and induced apoptosis and cell cycle arrest in MM cells, miR-590-5p may function as a tumor suppressor gene in MM.

Previously, it was reported that miR-590-5p was downregulated and functions as a tumor suppressor gene in various cancer types, including colorectal cancer $(36,37)$ and breast cancer (20). Meanwhile, miR-590-5p was demonstrated to be upregulated and function as an oncogene in cervical cancer (38), clear cell renal carcinoma (39) and gastric cancer (40). In hepatocellular carcinoma, there have been conflicting reports concerning the expression and function of miR-590-5p. Shan et al (41) reported that miR-590-5p was downregulated in six hepatocellular carcinoma cell lines, inhibited cell growth, induced cell cycle G1 arrest in HepG2 cells by suppressing Wnt family member $5 \alpha$, c-Myc, and cyclin D1 and increasing the phosphorylation of $\beta$-catenin and the expression of caspase-3. On the other hand, Jiang et al (42) 

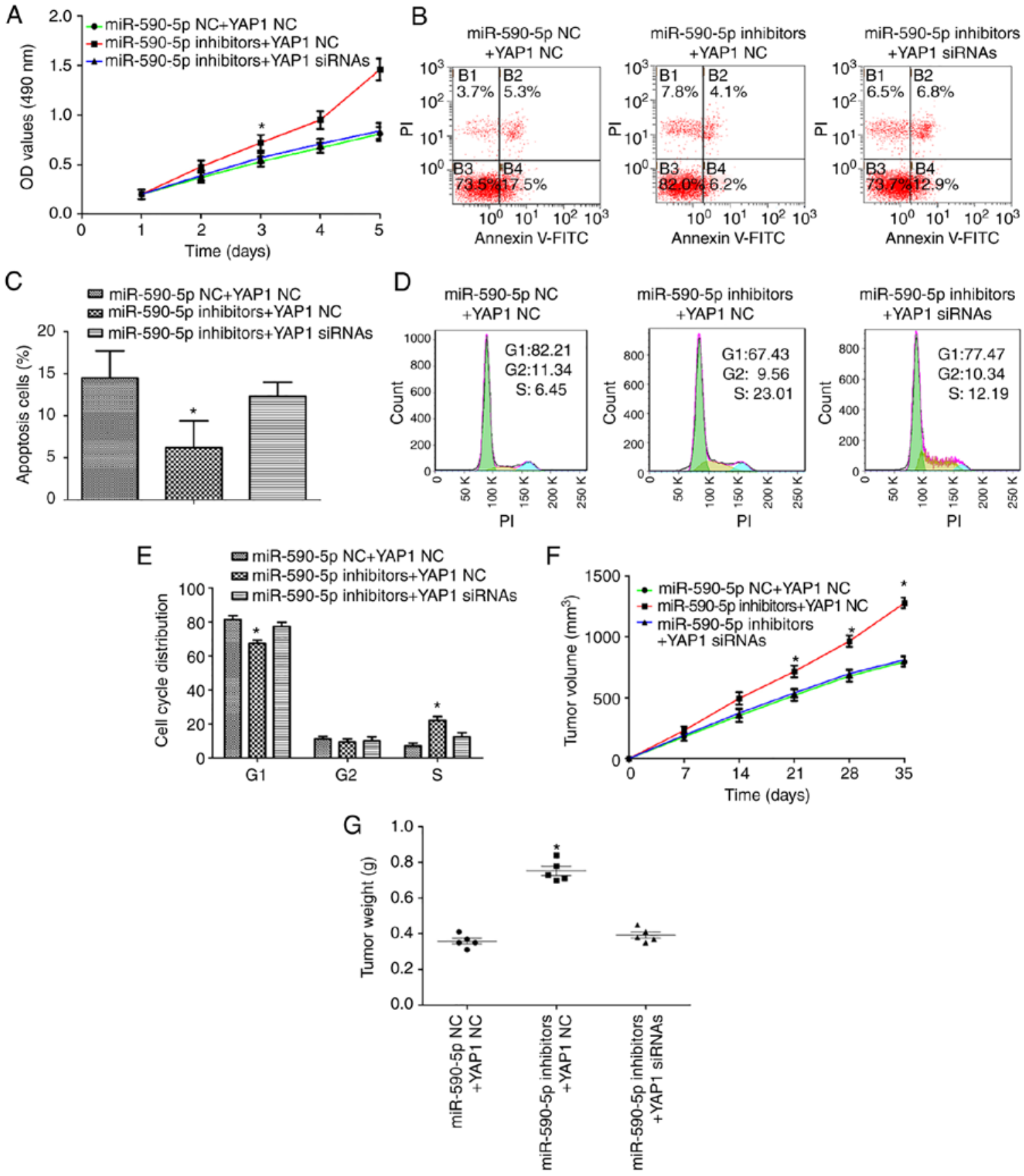

Figure 5. YAP1 was identified as a functional mediator of miR-590-5p in MM. (A) Silencing YAP1 counteracted the effects of miR-590-5p inhibitors on the cell proliferation of A375 cells. (B) Silencing YAP1 rescues the anti-apoptotic effects of miR590-5p inhibitors in A375 cells. (C) Quantification of (B). (D) Silencing YAP1 is able to rescue the effects of miR-590-5p inhibitors on cell cycle of A375 cells. (E) Quantification of (D). F, Silencing YAP1 may rescue the effects of miR-590-5p inhibitors on tumor growth of A375 cells. (G) Silencing YAP1 may rescue the effects of miR-590-5p inhibitors on tumor weight of A375 cells. Data are from three experiments and presented as the mean \pm standard deviation. "P $<0.05$ vs. respective NC group (Student's t-test). YAP1, Yes-associated protein 1; MM, malignant myeloma; miR, microRNA; NC, negative control; siRNA, small interfering RNA.

demonstrated that miR-590-5p levels were higher in HepG2 cells compared with the normal hepatocellular cell line $\mathrm{L}-\mathrm{O} 2$, and functioned as an oncogene to promote the tumor proliferation and invasion of hepatocellular carcinoma cells by directly targeting TGF- $\beta$ RII. The results of the present study support the tumor suppressor role of miR-590-5p in MM in the following ways: Firstly, miR-590-5p was downregulated in MM cell lines; secondly, miR-590-5p exerted anti-tumor effects in vitro and in vivo; and third, YAP1-which was identified as an oncogene and upregulated in various types of cancer $(43,44)$-was confirmed as the direct target and functional mediator of miR-590-5p in MM cells.

YAP1 is the key downstream effector of Hippo pathways (45). YAP1 functions as an oncogene and modulates numerous biological phenotypes of cancer cells, including proliferation (46), invasion (47), cell cycle progression (48) and cell differentiation (49). YAP1 was identified to be overexpressed in numerous types of cancer, and is an independent prognostic predictor of cancer $(50,51)$. In MM, YAP1-enhanced tumor progression and metastasis through interacting with the 
TEA domain transcription factor/TEF, PAR BZIP transcription factor family of transcription factors (52). Furthermore, the high expression of YAP1 was significantly associated with the poor outcome of patients with MM (53). Gene variants of YAP1 also proved to be independently associated with survival in patients with cutaneous melanoma (54). Consistent with these previous studies, the present study revealed that YAP1 was upregulated in MM cells. Furthermore, YAP1 was identified to be the direct target and functional mediator of miR-590-5p in MM cells.

It was previously reported miR-590-5p may inhibit the migration and invasion of cancer cells via the suppression of YAP1 expression (21). The focus of this previous study was the effects of miR-590-5p on the migration and invasion of A375 cells. Though it provided preliminarily evidence that the functions of miR-590-5p on the migration and invasion of A375 cells may be mediated by YAP1, this hypothesis was not confirmed through the use of rescue experiments. In the present study, the roles of miR-590-5p on the proliferation of A375 and A2058 cells were investigated in detail. Rescue experiments were also performed to confirm that the effect of miR-590-5p on the proliferation of MM cells was mediated by YAP1. It was revealed that silencing YAP1 is able rescue the effects of miR-590-5p inhibitors on the cell cycle and tumor growth of A375 cells. Therefore, in addition to the results of the previous study, present understanding of the role of YAP1 in the carcinogenesis and progression of MM was furthered.

In conclusion, the present study provided evidence that miR-590-5p directly inhibits YAP1 to reduce the proliferation and induce apoptosis of MM cells in vitro and is able to suppress tumor growth in vivo. Enhanced understanding of the process including cell proliferation and apoptosis that are regulated by miR-590-5p, and the identification of critical targets for miR-590-5p including YAP1, provides novel insight into the mechanism of carcinogenesis and progression in MM.

\section{Acknowledgements}

Not applicable.

\section{Funding}

The present study was supported by the Foundation of the First Affiliated Hospital of Xi'an Jiaotong University (grant no. 2016QN-06), the Fundamental Research Fund for Central Universities (grant no. xjj2018122) and the Shaanxi Nature Science Foundation (grant no. 2018JQ8027).

\section{Avaliability of data and materials}

The datasets used and/or analyzed during the current study are available from the corresponding author on reasonable request.

\section{Author contributions}

LW conceived and designed the experiments. KM, MD and DH performed the experiments. XM and YZ analyzed the data. WL contributed reagents, materials and analysis tools. $\mathrm{KM}$ and LW wrote the manuscript.

\section{Ethics approval and consent to participate}

The experimental study was approved by the Ethics Committee of Xi'an Jiaotong University (Xi'an, China), and informed consent forms were obtained when the patients who received circumcision at the First Affiliated Hospital of Xi'an Jiaotong University were accepted for the study. All procedures performed in the study involving human foreskin specimens were in accordance with the ethical standards of the Institutional and/or National Research Committee and with the 1964 Helsinki declaration and its later amendments or comparable ethical standards. All the patients enrolled in this study provided written informed consent for the use of their excised foreskin.

\section{Patient consent for publication}

Not applicable.

\section{Competing interests}

The authors declare that they have no competing interests.

\section{References}

1. Coricovac D, Dehelean C, Moaca EA, Pinzaru I, Bratu T, Navolan D and Boruga O: Cutaneous melanoma-A long road from experimental models to clinical outcome: A review. Int J Mol Sci 19: E1566, 2018.

2. Siegel RL, Miller KD and Jemal A: Cancer statistics, 2017. CA Cancer J Clin 67: 7-30, 2017.

3. Balch CM, Gershenwald JE, Soong SJ, Thompson JF, Atkins MB, Byrd DR, Buzaid AC, Cochran AJ, Coit DG, Ding S, et al: Final version of 2009 AJCC melanoma staging and classification. J Clin Oncol 27: 6199-6206, 2009.

4. Roukos DH: PLX4032 and melanoma: Resistance, expectations and uncertainty. Expert Rev Anticancer Ther 11: 325-328, 2011.

5. Tsai J, Lee JT, Wang W, Zhang J, Cho H, Mamo S, Bremer R, Gillette S, Kong J, Haass NK, et al: Discovery of a selective inhibitor of oncogenic B-Raf kinase with potent antimelanoma activity. Proc Natl Acad Sci USA 105: 3041-3046, 2008.

6. Eggermont AM, Spatz A and Robert C: Cutaneous melanoma. Lancet 383: 816-827, 2014.

7. Adams BD, Parsons C, Walker L, Zhang WC and Slack FJ: Targeting noncoding RNAs in disease. J Clin Invest 127: 761-771, 2017.

8. Moreno-Moya JM, Vilella F and Simón C: MicroRNA: Key gene expression regulators. Fertil Steril 101: 1516-1523, 2014.

9. Su Z, Yang Z, Xu Y, Chen Y and Yu Q: MicroRNAs in apoptosis, autophagy and necroptosis. Oncotarget 6: 8474-8490, 2015.

10. Zhou K, Liu M and Cao Y: New insight into microRNA functions in cancer: Oncogene-microRNA-tumor suppressor gene network. Front Mol Biosci 4: 46, 2017.

11. Wozniak M, Mielczarek A and Czyz M: miRNAs in melanoma: Tumor suppressors and oncogenes with prognostic potential. Curr Med Chem 23: 3136-3153, 2016.

12. Wang Z, Zheng C, Jiang K, He J, Cao X and Wu S: MicroRNA-503 suppresses cell proliferation and invasion in osteosarcoma via targeting insulin-like growth factor 1 receptor. Exp Ther Med 14: 1547-1553, 2017.

13. Xu L, Xu Q, Li X and Zhang X: MicroRNA-21 regulates the proliferation and apoptosis of cervical cancer cells via tumor necrosis factor- $\alpha$. Mol Med Rep 16: 4659-4663, 2017.

14. Markopoulos GS, Roupakia E, Tokamani M, Vartholomatos G, Tzavaras T, Hatziapostolou M, Fackelmayer FO, Sandaltzopoulos R, Polytarchou C and Kolettas E: Senescenceassociated microRNAs target cell cycle regulatory genes in normal human lung fibroblasts. Exp Gerontol 96: 110-122, 2017.

15. Qin W, Rong X, Dong J, Yu C and Yang J: miR-142 inhibits the migration and invasion of glioma by targeting Rac1. Oncol Rep 38: 1543-1550, 2017. 
16. Guo W, Wang H, Yang Y, Guo S, Zhang W, Liu Y, Yi X, Ma J, Zhao T, Liu L, et al: Down-regulated miR-23a contributes to the metastasis of cutaneous melanoma by promoting autophagy. Theranostics 7: 2231-2249, 2017.

17. Bai M, Zhang M, Long F, Yu N, Zeng A and Zhao R Circulating microRNA-194 regulates human melanoma cells via PI3K/AKT/FoxO3a and p53/p21 signaling pathway. Oncol Rep 37: 2702-2710, 2017.

18. Guo S, Guo W, Li S, Dai W, Zhang N, Zhao T, Wang H, Ma J, Yi X, Ge R, et al: Serum miR-16: A potential biomarker for predicting melanoma prognosis. J Invest Dermatol 136: 985-993, 2016.

19. Yang $\mathrm{X}$ and $\mathrm{Wu} \mathrm{X}$ : miRNA expression profile of vulvar squamous cell carcinoma and identification of the oncogenic role of miR-590-5p. Oncol Rep 35: 398-408, 2016.

20. Zhou L, Zhao LC, Jiang N, Wang XL, Zhou XN, Luo XL and Ren J: MicroRNA miR-590-5p inhibits breast cancer cell stemness and metastasis by targeting SOX2. Eur Rev Med Pharmacol Sci 21: 87-94, 2017.

21. Wang L, Shi S, Zhou Y, Mu X, Han D, Ge R and Mu K miR-590-5p inhibits A375 cell invasion and migration in malignant melanoma by directly inhibiting YAP1 expression. Xi Bao Yu Fen Zi Mian Yi Xue Za Zhi 33: 326-330, 2017 (In Chinese).

22. Livak KJ and Schmittgen TD: Analysis of relative gene expression data using real-time quantitative PCR and the 2(-Delta Delta C(T)) method. Methods 25: 402-408, 2001.

23. Workman P, Aboagye EO, Balkwill F, Balmain A, Bruder G, Chaplin DJ, Double JA, Everitt J, Farningham DA, Glennie MJ, et al: Guidelines for the welfare and use of animals in cancer research. Br J Cancer 102: 1555-1577, 2010.

24. Agarwal V, Bell GW, Nam JW and Bartel DP: Predicting effective microRNA target sites in mammalian mRNAs. Elife, 2015.

25. Chen K and Rajewsky N: Natural selection on human microRNA binding sites inferred from SNP data. Nat Genet 38: 1452-1456, 2006.

26. Enright AJ, John B, Gaul U, Tuschl T, Sander C and Marks DS: MicroRNA targets in Drosophila. Genome Biol 5: R1, 2003.

27. Legras A, Pécuchet N, Imbeaud S, Pallier K, Didelot A, Roussel H, Gibault L, Fabre E, Le Pimpec-Barthes F, Laurent-Puig P and Blons H: Epithelial-to-mesenchymal transition and MicroRNAs in lung cancer. Cancers 9: E101, 2017.

28. Varamo C, Occelli M, Vivenza D, Merlano $M$ and Lo Nigro C: MicroRNAs role as potential biomarkers and key regulators in melanoma. Genes Chromosomes Cancer 56: 3-10, 2017.

29. Deng Z, Hao J, Lei D, He Y, Lu L and He L: Pivotal MicroRNAs in melanoma: A mini-review. Mol Diagn Ther 20: 449-455, 2016.

30. Grignol V, Fairchild ET, Zimmerer JM, Lesinski GB, Walker MJ, Magro CM, Kacher JE, Karpa VI, Clark J, Nuovo G, et al: miR-21 and miR-155 are associated with mitotic activity and lesion depth of borderline melanocytic lesions. Br J Cancer 105: 1023-1029, 2011.

31. Satzger I, Mattern A, Kuettler U, Weinspach D, Niebuhr M, Kapp A and Gutzmer R: microRNA-21 is upregulated in malignant melanoma and influences apoptosis of melanocytic cells. Exp Dermatol 21: 509-514, 2012.

32. Martin del Campo SE, Latchana N, Levine KM, Grignol VP, Fairchild ET, Jaime-Ramirez AC, Dao TV, Karpa VI, Carson M, Ganju A, et al: MiR-21 enhances melanoma invasiveness via inhibition of tissue inhibitor of metalloproteinases 3 expression: In vivo effects of MiR-21 inhibitor. PloS One 10: e0115919, 2015

33. Zhang J, Lu L, Xiong Y, Qin W, Zhang Y, Qian Y, Jiang H and Liu W: MLK3 promotes melanoma proliferation and invasion and is a target of microRNA-125b. Clin Exp Dermatol 39: 376-384, 2014

34. Kappelmann M, Kuphal S, Meister G, Vardimon L and Bosserhoff AK: MicroRNA miR-125b controls melanoma progression by direct regulation of c-Jun protein expression. Oncogene 32: 2984-2991, 2013.

35. Alegre E, Sanmamed MF, Rodriguez C, Carranza O, MartinAlgarra $S$ and Gonzalez A: Study of circulating microRNA-125b levels in serum exosomes in advanced melanoma. Arch Pathol Lab Med 138: 828-832, 2014

36. Ou C, Sun Z, Li X, Li X, Ren W, Qin Z, Zhang X, Yuan W, Wang J, Yu W, et al: MiR-590-5p, a density-sensitive microRNA, inhibits tumorigenesis by targeting YAP1 in colorectal cancer. Cancer Lett 399: 53-63, 2017.
37. Zhou Q, Zhu Y, Wei X, Zhou J, Chang L, Sui H, Han Y, Piao D, Sha R and Bai Y: MiR-590-5p inhibits colorectal cancer angiogenesis and metastasis by regulating nuclear factor 90/vascular endothelial growth factor A axis. Cell Death Dis 7: e2413, 2016.

38. Chu Y, Ouyang Y, Wang F, Zheng A, Bai L, Han L, Chen Y and Wang H: MicroRNA-590 promotes cervical cancer cell growth and invasion by targeting CHL1. J Cell Biochem 115: 847-853, 2014.

39. Xiao X, Tang C, Xiao S, Fu C and Yu P: Enhancement of proliferation and invasion by MicroRNA-590-5p via targeting PBRM1 in clear cell renal carcinoma cells. Oncol Res 20: 537-544, 2013.

40. Shen B, Yu S, Zhang Y, Yuan Y, Li X, Zhong J and Feng J: miR-590-5p regulates gastric cancer cell growth and chemosensitivity through RECK and the AKT/ERK pathway. Onco Targets Ther 9: 6009-6019, 2016.

41. Shan X, Miao Y, Fan R, Qian H, Chen P, Liu H, Yan X, Li J and Zhou F: MiR-590-5P inhibits growth of HepG2 cells via decrease of S100A10 expression and inhibition of the Wnt pathway. Int J Mol Sci 14: 8556-8569, 2013.

42. Jiang X, Xiang G, Wang Y, Zhang L, Yang X, Cao L, Peng H, Xue $P$ and Chen D: MicroRNA-590-5p regulates proliferation and invasion in human hepatocellular carcinoma cells by targeting TGF- $\beta$ RII. Mol Cells 33: 545-551, 2012.

43. Zanconato F, Cordenonsi M and Piccolo S: YAP/TAZ at the Roots of Cancer. Cancer Cell 29: 783-803, 2016.

44. Zanconato F, Battilana G, Cordenonsi M and Piccolo S: YAP/TAZ as therapeutic targets in cancer. Curr Opin Pharmacol 29: 26-33, 2016.

45. Shibata M, Ham K and Hoque MO: A time for YAP1: Tumorigenesis, immunosuppression and targeted therapy. Int $\mathrm{J}$ Cancer: Apr 26, 2018 (Epub ahead of print). doi: 10.1002/ijc.31561.

46. Seo WI, Park S, Gwak J, Ju BG, Chung JI, Kang PM and Oh S: Wnt signaling promotes androgen-independent prostate cancer cell proliferation through up-regulation of the hippo pathway effector YAP. Biochem Biophys Res Commun 486: 1034-1039, 2017.

47. LeeHJ,DiazMF,PriceKM,OzunaJA,ZhangS,Sevick-MuracaEM, Hagan JP and Wenzel PL: Fluid shear stress activates YAP1 to promote cancer cell motility. Nat Commun 8: 14122, 2017.

48. Strnadel J, Choi S, Fujimura K, Wang H, Zhang W, Wyse M, Wright T, Gross E, Peinado C, Park HW, et al: eIF5A-PEAK1 signaling regulates YAP1/TAZ protein expression and pancreatic cancer cell growth. Cancer Res 77: 1997-2007, 2017.

49. Fan Y, Gao Y, Rao J, Wang K, Zhang F and Zhang C: YAP-1 promotes tregs differentiation in hepatocellular carcinoma by enhancing TGFBR2 transcription. Cell Physiol Biochem 41: 1189-1198, 2017.

50. Lee K, Lee KB, Jung HY, Yi NJ, Lee KW, Suh KS and Jang JJ: The correlation between poor prognosis and increased yes-associated protein 1 expression in keratin 19 expressing hepatocellular carcinomas and cholangiocarcinomas. BMC Cancer 17: 441, 2017.

51. Hu X, Chen J and Fu Q: Downregulation of YAP in clear cell renal cell carcinoma contributes to poor prognosis and progressive features. Ann Clin Lab Sci 47: 36-39, 2017

52. Lamar JM, Stern P, Liu H, Schindler JW, Jiang ZG and Hynes RO: The Hippo pathway target, YAP, promotes metastasis through its TEAD-interaction domain. Proc Natl Acad Sci USA 109: E2441-E2450, 2012

53. Menzel M, Meckbach D, Weide B, Toussaint NC, Schilbach K, Noor S, Eigentler T, Ikenberg K, Busch C, Quintanilla-Martinez L, et al: In melanoma, Hippo signaling is affected by copy number alterations and YAP1 overexpression impairs patient survival. Pigment Cell Melanoma Res 27: 671-673, 2014.

54. Yuan H, Liu H, Liu Z, Zhu D, Amos CI, Fang S, Lee JE and Wei Q: Genetic variants in Hippo pathway genes YAPl, TEADI and TEAD4 are associated with melanoma-specific survival. Int J Cancer 137: 638-645, 2015.

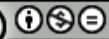

This work is licensed under a Creative Commons Attribution-NonCommercial-NoDerivatives 4.0 International (CC BY-NC-ND 4.0) License. 